Данијела Р. ПЕТКОВИЋ*

Институт за књижевност и уметност Београд
Оригинални научни рад

Примљен: 20. 11. 2018.

Прихваћен: 14. 02. 2019.

\title{
ФОЛКЛОР НА СТРАНИЦАМА ПРИЛОГА ЗА КЬИЖЕВНОСТ ЈЕЗИК, ИСТОРИЈУ И ФОЛКЛОР ИЗМЕЂУ ДВА СВЕТСКА РАТА**
}

Текстови из области фолклористике заузимају запажено место у међуратним Прилозима за књижевност, језик, историју и фолклор. Међу 350 радова, у виду расправа, ситних прилога и осврта на нова издања, доминирају они који испитују мотиве, варијанте, њихово порекло и путеве преношења, а иза тога следе истраживања историјског језгра усмене поезије. Осим тематике, све прилоге повезује сличан методолошки приступ, у коме предњачи компаративни метод. Оваква концепција блиска је идејама и научно-критичкој позицији Павла Поповића, оснивача и уредника Прилога, у којима такође запажену улогу имају и Веселин Чајкановић и Тихомир Ђорђевић. Кад је реч о доминантној тематици и методама у међуратној фолклористици, Прилози за књижевност, језик, историју и фолклор налазе се на супротној позицији у односу на Прилоге проучавању народне поезије, а Српски кьижевни гласник је на средокраћи између ова два гласила.

Кључне речи: фолклористика између два рата, Прилози за књижевност, језик, историју и фолклор, Павле Поповић, Веселин Чајкановић, Тихомир Ђорђевић.

После I светског рата интелектуална елита новостворене заједничке државе Јужних Словена настојала је да успостави прекинути научноистраживачки континуитет. Тако се у области друштвених наука обнављају угашена друштва и часописи, а такође се оснивају и нова гласила као одраз појачаног интересовања за хуманистичке дисциплине. О томе сведочи Павле Поповић у уводном обраћању културној и научној јавности на почетку првог броја Прилога за књижевност, језик, историју и фолклор, које је покренуо 1921. и потом уређивао безмало две деценије. Задаци које је на истом месту изнео, а то су ширење интереса за националне хуманистичке науке, удру-

* petkovic.danijela@yahoo.com

** Рад је настао на пројекту „Српско усмено стваралаштво у интеркултурном коду” (бр. 178011), који финансира Министарство просвете, науке и технолошког развоја Републике Србије. 
живање научних снага и израз научних резултата специјалистичких области, као што су усмена и писана књижевност ${ }^{1}$, политичка, културна, црквена историја, језик, митологија, историја религије и друге сродне дисциплине, спровођени су доследно од првог до последњег броја међуратних Прилога (Поповић 1921: I-III).

Природно је што је у овако широком обухвату разноврсних, а ипак сродних поља истраживања, фолклористика, прожета сваким од њих и заинтересована за њихове резултате, нашла плодно тло и складно се уклопила у прецизну уредничку концепцију. Фолклористички чланци, било да су међу „Расправама”, „Ситним прилозима” или у рубрици „Књиге и расправе (реферати)", заузимају запажено место на страницама Прилога. То потврђује и текст Љубомира Стојановића о младом Вуку Караџићу, који је отворио часопис (1921: 1-11), а и сам Павле Поповић када истиче колика је била част за редакцију што је „у првој години, у првом броју, на првом месту” објавила тај рад (1931: 39). Интересантно је да је први чланак последњег броја Прилога пред II светски рат, и уједно Поповићев последњи, посмртно објављен текст у овом листу, такође посвећен цртицама из Вукових позних година (1940: 1-7). Симболично, затворен је круг, а у њему је за двадесетак година објављено око 350 фолклористичких текстова и бележака.

Осим Љ. Стојановића, који је у првом десетлећу објавио у Прилозима само још један фолклористички чланак (о Рељи од Пазара - 1922: 88), мада је био присутан кроз белешке и приказе монографије о Вуку (Миљковић 1921: 139; Поповић 1924: 301-307; Поповић 1926: 115), као и у сећању савременика у броју уприличеном поводом његове смрти (1931), значајни су и радови Тихомира Ђорђевића (о пословицама - 1921a: 224-230; 1940a: 153-156; apбанашким народним песмама - 1933: 28-43; Наср-един хоџи - 1935а: 195; 1937a: 270; 1940б: 153; лошем оделу као заштити од урока - 1935б: 47-55; кувади - 1936а: 199-213; полагању самртника на земљу - 1938а: 468-474; порођајним демонима - 1940в: 8-26, итд.), Веселина Чајкановића (о пословицама - 1921а: 65-70; 1921б: 203-211; божићној слами - 1923: 123-132; заклињању откривањем груди - 1926а: 49-53; орасима у обреду венчања - 1937а: 94-101; обичају остављања деце - 1937б: 249-252; о мотиву пропасти и обнови света у митологији и народној епици - 1938: 475-494; о мотиву преваре смрти - 1940: 142-149, итд.), Бошка Деснице (документи из млетачких архива о ускочким првацима, јунацима епске поезије - 1922: 196-200; 1924: 88-91; 1926: 206-218; 1927: 179-188; 1930: 77-82), Лазара Мирковића (о црквеном утицају на усмену поезију и обичаје - 1923a: 231-236; 1923б: 141-149; 1926: 202-205), Владимира Ћоровића (о предању о убиству цара Уроша - 1921: 190-202; о Љ. Стојановићу - 1931: 1-29; Јовану Томићу 1932: 71-100), Фехима Барјактаревића (о мевлудима, песмама о Мухамедовом рођењу - 1930: 83-87; 1937: 1-37; предању о потопу 1934а: 193-194; Насредин-хоџи 1934б: 81-52). Од стотинак фолклористичких прилога, не ра-

\footnotetext{
${ }^{1}$ Појава Прилога, према речима М. Матицког, значила је добијање аутономије за научне књижевне часописе (2003: 50).
} 
чунајући приказе и белешке, поменути аутори написали су око половину, од тога највише Т. Ђорђевић (преко 15) и В. Чајкановић (близу 10), једини „сауредници" Павла Поповића у свим бројевима прве серије Прилога, заједно са В. Ћоровићем. Међу сарадницима били су и познати страни слависти тога доба: Јиржи Поливка (чланак о приповеткама о метаморфози пола - 1927: 1-22), Андре Вајан (о узвику давори у народним песмама - 1933: 77-80), Андре Мазон (о курсевима о српској и грчкој народној поезији на Сорбони - 1938: 458-467), Артуро Кронија (о Алберту Фортису и нашој поезији - 1938: 546-553), Евгеније Љацки (о проучавању епске поезије 1936: 1-8 и аналогијама руске и српске епике -1938: 495-499), Алојз Шмаус (о Курипешићевом извештају о Косовском боју - 1938: 509-518), Герхард Геземан (о новијим теренским збиркама приповедака из Црне Горе - 1938: 577-579), а њихов рад је редовно праћен и кроз приказе и реферате. Само су 1929. и 1932. г. изостале фолклористичке студије, али не и извештаји о текућим фолклористичким издањима.

Сумарни преглед ових текстова у првим двема рубрикама, међу ширим и ситнијим прилозима, открива сличну тематску оријентацију и заједнички методолошки приступ. Тако, највећи број чланака разматра и тумачи поједини мотив кроз низ домаћих и страних варијаната (у оквиру усменог текста, обичаја, обреда) и утврђује његово порекло и путеве преношења. Као посебна група оваквих истраживања издвајају се бројни радови на страницама Прилога о вези усмене и писане књижевности - нпр. фолклорни мотиви код Вергилија (Будимир 1925: 160-179), Матије Дивковића и Вићентија Ракића (Стевановић 1938: 595-601), Видаковића (Лесковац 1936: 133-135), Враза (Ковачевић 1932: 169-170), Сремца (Чајкановић 1925a: 241), у савременом немачком роману (Ђорђевић М. 1938: 612-616), или књижевни мотиви у усменим обрадама, потекли нпр. из грчке културе (Ђорђевић 1935а: 196-197), из црквених песама (Мирковић 1926: 202-205), из Дантеовог Пакла (Банашевић 1938: 519-525), итд. Приметно је да препознатљив компаративни метод миграционе и потоње историјско-географске школе доминира у међуратним Прилозима.

Друга, много мања група фолклористичких радова занимала се проучавањем историјске основе фолклорних мотива и јунака (поменути текст В. Ћоровића о смрти цара Уроша у историји и предању - 1921: 190-202, „О мартолосима у турској војсци” Душана Поповића - 1928: 213-229, поменути радови Б. Деснице), испитивањем путева поетског преобликовања првобитног историјског језгра (нпр. В. Ћоровић у тексту посвећеном Ј. Томићу - 1932: 88-91; такође и спомињани чланци Евгенија Љацког) и утврђивањем историјских прототипова појединих епских јунака (поменути текст Љ. Стојановића о Рељи од Пазара - 1922: 88; расправе Ј. Томића, Т. Маретића и В. Чубриловића о Иви Сењанину - 1928: 1-11; 1930: 245-246; 1938: 526-545). Ако је српска фолклористика између два рата по нечему била препознатљива, то је пасионирано трагање за епским узорима и историјским догађајима који су могли дати почетни импулс епским сижеима. Научници, културни посленици, па чак и они који то нису - лаици, патриоте, љубитељи историје и старина, 
утркивали су се на страницама дневних и научних гласила у дешифровању замућене историје коју су запамтили епски стихови. Састављајући дугу листу новина и часописа који штампају историјске прилоге, В. Ћоровић управо у Прилозима сведочи о својеврсној помами за овом врстом истраживања на нашем поднебљу ${ }^{2}$, а Ђорђе Живановић поставља питање: „Да ли баш за сваку ситницу из народних песама треба тражити потврде у изворима?" (1936: 158). Ваља истаћи да су Прилози за кюижевност, језик, историју и фолклор, кад је реч о овој популарној тенденцији, задржали дозу фине академске мере - проучавање историјске основе усмене поезије није било доминантно, далеко су бројнија компаративна истраживања мотива и варијаната. Са страница Прилога стижу упозорења на клиско тло закључака који почивају на несигурним и малобројним историјским фактима, чије су импликације у тумачењу усмене поезије неретко исконструисане. Прекори су највише били упућени Драгутину Костићу, који је предњачио у утврђивању реалних прототипова и збивања у епској поезији и за којег зато у академским Прилозима није било места $^{3}$, будући да су се у њима захтевале добра обавештеност, обазривост и критичност и оспоравали ,лако тражење историјских реминисценција у народној поезији” и „метод домишљања” (Ћоровић 1936: 177; Поповић 1937а: 297-298, Банашевић 1935: 229-230; Банашевић 1936а: 121).

Трећој групи фолклористичких текстова у Прилозима, такође не тако бројној, припадају биобиблиографски чланци о познатим фолклористима. Налазе се међу ширим и краћим студијама, а понегде и у форми приказа или читуља на крају друге свеске појединих годишта (в. нпр. читуље посвећене Ј. Поливки - Љацка 1933: 244-245 и С. Тројановићу - Ђорђевић 1936б: 414-415). Бројеви делимично посвећени успомени на Љ. Стојановића (1931) и J. Томића (1932) донели су и прилоге о њиховом животу и раду. Цртице из Вуковог живота откривају Љ. Стојановић (1921: 1-11), П. Поповић (1924: 301-307; 1940: 1-7), Момчило Селесковић (1937: 81-89), а употпуњавају их и ексклузивно објављена, дотад непозната писма (Радојчић 1925: 223-225; Томановић 1934: 186-188). Понешто о лику и делу чувеног енглеског етнолога Џејмса Џорџа Фрејзера сазнаје се из две од низа бележака Т. Ђорђевића о његовим радовима (1932а: 285-287; 1937б: 350-351) и једне В. Поповића (1934: 215-216). О преводиоцима наше усмене поезије - Овену Мередиту и Џону Баурингу писали су П. Поповић (1922a: 106-109) и Владета Поповић (1938: 554-564).

Преглед фолклористичких чланака у Прилозима не би био ни издалека потпун без текстова у одељку „Књиге и расправе (реферати)”. Ова веома

\footnotetext{
2 „Оволико хисториског интереса није било никад пре, иако су хисториска питања и расправљања о њима била одувек врло присна нашем народу. Било би занимљиво утврдити поближе, који су све разлози за ово јачање хисториског интереса, који наводи толике људе, из разних струка и области, да се занимају тим питањима и да и сами доносе своје прилоге. Извесне обнове хисторизма има данас у целом свету, али га, сразмерно, у оволикој мери као код нас ја нисам могао утврдити ни на једној другој страни. У нас драматурзи праве тезе из хисторије; од млађих наших књижевника и песника понајвише их је радило хисторију као свој главни стручни предмет" (Һоровић 1929: 208).

${ }^{3}$ Подробније о овоме - Петковић 2017: 91-92.
} 
важна рубрика у Прилозима заузимала је готово трећину садржаја. За непуне две деценије, у њој је објављено близу 250 бележака и приказа чланака, књига и часописа из области фолклористике, од чега су половину написали В. Чајкановић и Т. Ђорђевић, први више у првом десетлећу часописа, а други у другом. Чајкановић је испратио домаће и стране радове (немачке, француске, енглеске) претежно из области митологије, магије, историје античке, германске, словенске религије, поједине бројеве Zbornika za narodni život i običaje Južnih Slavena, Гласника Етнографског музеја, док је Т. Ђорђевић нотирао наше и европске етнолошке радове, нарочито оне у енглеској науци (издања и преводи Фрејзерових текстова, часопис Folk-Lore), посебно се интересујући за изучавања арбанашке и циганске усмене традиције. П. Поповић је континуирано пратио зборнике и часописе у којима је било и фолклористичких прилога (Глас CКА, чешку Slaviu, француску Revue des Études Slaves), а у складу са својим истраживањима усмене књижевности - нове збирке народних приповедака и издања и преводе Вукових књига. Међу осталим, бројним ауторима приказа и бележака издвајају се они који су се специјализовали за поједине области и језичка подручја. Тако је Фехим Барјактаревић пратио истраживања оријенталне фолклористике (арапске, персијске, турске, иранске) на простору Балкана, Истока и водећих европских научних центара, Растислав Марић - радове из области класичне старине, Михаило Ласкарис - грчка и румунска издања, Фран Илешић - чешку и пољску фолклористику, Едуард Турек - чешку, Едмунд Шневајс је извештавао о немачким радовима, а М. Мајзнер о немачким издањима европских бајки. Упадљиво је одсуство прегледа руских фолклористичких истраживања. Познавање језика није било спорно, сваки научник тога доба био је врсни ерудита и зналац више светских и класичних језика. ${ }^{4}$ Разлоге треба тражити у владајућим политичко-економским, друштвеним и научно-критичким струјањима у међуратној Југославији. Окретање ка Западној Европи, школовање наше интелигенције на француским и енглеским универзитетима, одакле су доносили нове идеје, затим политичко удаљавање од бољшевичке Русије и сарадња са руском научном емиграцијом у Прагу, разлог су слабог присуства актуелне руске фолклористике на страницама Прилога.

\footnotetext{
${ }^{4}$ Међу уредницима и сарадницима Прилога између два светска рата, као уосталом и у ширем научном кругу тога доба, било је одличних познавалаца светских језика и европских токова науке. Знање је подразумевано и кад је реч о рецепцији - аутори у Прилозима не преводе стране цитате, а Чајкановић пише и на латинском (1921a: 65-70; 1926а: 49-53; 1938: 475-494). Међуратни период Деретић види као време доминације критике, „златно доба научне прозе”, када наши хуманисти умногоме превазилазе домаћу средину $(2004: 915,931)$. И заиста, наши фолклористи не само да су стајали раме уз раме са европским и објављивали своје текстове у познатим европским гласилима, него су своје колеге неретко надилазили по знању и ширини приступа, бивајући принуђени да исправљају тврђења оних који су претендовали на тумачење наше усмене традиције без довољног познавања проблематике културе, основне литературе, а врло често и нашег језика. Честе критике страних слависта који су се упустили у такав посао стизале су и са страница Прилога. Чајкановић, на пример, указује Шневајсу на грешке и пропусте - 1925б: 318-322; 1937в: 351-352, а М. Филиповић критикује енглеску фолклористкињу Олив Лоџ, оштро коментаришући да би боље било да је превела неки наш етнолошки чланак него што је покушала да тумачи српске свадбене обичаје (1937: 180-182).
} 
Прикази су у Прилозима ретко остајали на нивоу представљања садржаја, а белешке, макар и сасвим кратке, само изузетно су се сводиле на пуко нотирање. Уз кратке осврте на раније радове, претходна издања или преводе, обавезно су додавани и подаци о сличним мотивима у нашој или страној фолклористици, указивано је на варијанте, њихове изворе и научне текстове који се њима баве. У том погледу преглед издања и концепцијски и методолошки потпуно следи шире и краће студије из првих двеју рубрика Прилога. Поједини прикази вишеструко су надрастали своје оквире, претварајући се одмах након кратког уводног реферата о делу и аутору у мале расправе о питању које је извесни текст отворио. Тако је Чајкановићев осврт на Шневајсову монографију о српском Божићу више тумачење божићних обичаја и природе старе српске религије (1925б: 318-322), а Ђорђевићев приказ чланка Вејсила Ћурчића о старинском оружју већим делом је нови, бољи, много документованији и подробнији текст на исту тему (1927: 336-342). Сам наслов рубрике „Књиге и расправе” предвиђао је разраду питања које приказано издање иницира.

Рубрика је, према сведочењу П. Поповића на почетним странама првог броја, замишљена као наставак наставничког рада универзитетских професора, носилаца Прилога. Амбициозан план предвиђао је праћење целокупног истраживања у области хуманистичких наука. Полазећи од максиме да је нотирање књига већ половина учења, П. Поповић је кроз концепцију систематског, прецизног, континуираног, свеобухватног бележења, али и оцењивања књига испуњавао један од најважнијих програмских задатака листа, постављен већ 1921, а то је ширење интереса за науку и усмеравање и организовање научног рада (1921: III-IV). Ако је помно бележење хуманистичких издања доприносило ширењу интереса за науку, онда је обиље коментара и вредносних процена које су реферати о књигама и чланцима садржали испуњавало овај други задатак - организовање и усмеравање научног рада, али и обликовање укуса публике.

Реферати о фолклористичким радовима и у овоме испуњавају предвиђену концепцију, јер је сваки нови резултат научног истраживања био детаљно критички процењиван. Кроз Поповићево, Чајкановићево, Ђорђевићево, Барјактаревићево решето пропуштане су нове теренске збирке и готово сваки научни закључак. Похвале, покуде, допуне и корекције, савети како треба радити, позиви на истраживање занемарених области уносили су у приказе, белешке и расправе елементе естетичке критике и дидактичке ноте. Постепено, заједничким снагама и сугестијама, водећи ауторитети међу ауторима фолклористичких реферата подучавали су колеге и пратили њихов рад. Као да су удружени исписивали методички приручник, практикум у коме износе позитивне и негативне примере ваљаног научног рада. Негативан пример лошег закључивања Ивана Касумовића да су све наше пословице које имају сличне мотиве са грчким и римским потекле из античких извора, искористио је тако В. Чајкановић да подучи сакупљаче и будуће компаратисте како доћи до тачних научних закључака. Саветује им испитивање аутентичности извора, проверу путева преношења, проучавање варијаната, прелазних спо- 
на, опрезност у тврђењима, чување од лаког, једностраног закључивања итд. (1922a: 284-288; 1922б: 288-289). У низу осврта на сакупљену усменопоетску грађу и Вукове настављаче, Ђорђевић објашњава како ваљано приређивати теренске збирке - обавезно је верно записивање, неулепшавање језика, бележење имена казивача, места записивања, тематско сређивање (в. нпр. 1931: 243-250). Поједини приређивачи, као што су нпр. Стјепан Грчић или Новица Шаулић, праћени су у континуитету (о књигама С. Грчића - Ђорђевић 1921б: 131-132; 1932б: 158; 1932в: 285; о књигама Н. Шаулића - Поповић 1922б: 100-101; Чајкановић 1926б: 329-331; Ђорђевић 1931: 243-250; Поповић 1932: 283-285; Ђорђевић 1936в: 187). Сваку њихову збирку дочекивала је белешка која је истицала добра места, указивала на грешке, подсећала на примедбе упућене аутору у ранијим бројевима Прилога, проверавала колико их је приређивач усвојио и евидентирала све чланке листа у којима је било речи о претходним збиркама.

Управо су тај увид у све и континуирано праћење произвели утисак да се фолклор на страницама међуратних Прилога исписивао као велика, вишетомна књига у наставцима, која је за две деценије излажења сачувала целовитост и исти курс. Томе у прилог говоре и бројни текстови различитих аутора на исту тему, који се из броја у број настављају (нпр. о опросном писму - Ђорђевић 1922: 80-81; Руварац 1922: 264-265; Мирковић 1923а: 231-236; Иви Сењанину - Томић 1928: 1-11; Маретић 1930: 245-246; Чубриловић 1938: 526-545; Насредин хоџи - Барјактаревић 1934б: 81-52; Ђорђевић 1935а: 195; 1937а: 270; 1940б: 153; изораном шарану - Поповић 1934: 241; Поленаковић 1937: 275; кратка допуна Т. Ђорђевића - 1937в: 275). Једна почетна идеја повлачила је аналогну или донекле опозитну реакцију, кориговање, појашњавање или макар упућивање на варијанте. Уобичајено је и допуњавање неког истраживања кратком белешком од неколико редака, одмах испод текста, у којој се наводе слични примери и потврђује изнесени закључак, што је неретко практиковао П. Поповић ${ }^{5}$, а често се скупно потписивало Уредништво.

Јавност је о фолклористичким истраживањима обавештавана и кроз извештаје са састанака разних друштава, на којима је практиковано читање актуелних радова њихових чланова. Прилози су редовно доносили ове извештаје, првих пет година у оквиру рубрике „Књиге и расправе”, а потом у посебном повременом одељку. За фолклористику су интересантни реферати о састанцима Друштва за српски језик и књижевност, које су потписивали Урош Џонић, први секретар Друштва, а потом и Људмила Михајловић и Драгољуб Павловић. Библиографија на крају сваког годишта, као опус појединог истакнутог научника или као списак књига и часописа које је уредништво добило кроз размену, такође је пружала увид у радове из области усмене традиције.

\footnotetext{
${ }_{5}^{5}$ Д. Павловић сведочи о брижљивом раду П. Поповића, који је био и уредник и сарадник - све радове је читао, исправљао, допуњавао, пишући и сам доста за рубрику „Књиге и расправе" (1959: 207).
} 
Општи поглед на све фолклористичке чланке у Прилозима открива да се по компаративном приступу, темељном проучавању путева преношења мотива, систематском пописивању варијаната, консултовању биографских података и историје, академској визури и вредносном процењивању они уклапају не само у концепцију целог часописа, него да су понајвише огледало његовог оснивача и главног уредника - Павла Поповића, у чијем се методолошком приступу комбинују изучавање архивске грађе, компаративно проучавање и анализа (Деретић 2004: 928), а у научно-критичкој позицији - ублажени теновски детерминизам, биографска критика Сент-Бева и историјска критика (Павловић 1959: 198; Палавестра 1979: 237-238; Деретић 2004: 1094) са критиком укуса (Милошевић Ђорђевић 2000: 129) и идејама миграционе теорије (Pešić, Milošević Đorđević 1984: 158). По оваквим гледиштима П. Поповић није био усамљен. Огроман научнички углед ${ }^{6}$ утицао је на мноштво следбеника, а управо је заједно с онима са којима је делио блиске научне ставове спровео у дело замисао о компактном методолошки и идејно усаглашеном гласилу. Тај дух јединства осетио се и у кохерентном друштвено-политичком ставу уредништва, које је бранило програмску концепцију југословенства о заједничкој историји књижевности ${ }^{7}$, третирајући нпр. целокупну усмену баштину као „нашу”. 8

Разматрање фолклористике на страницама Прилога за књижевност, језик, историју и фолклор мора укључити и однос према другим важним гласилима међуратног доба у којима су објављивана истраживања усменог наслеђа. У време када су Прилози оснивани, после I светског рата, велико интересовање за хуманистичке науке није било у корелацији с бројем њихових гласила. П. Поповић је предвиђао експанзију и покретање нових часописа у наредним годинама, како се хуманистичке науке буду све више гранале и специјализирале (Поповић 1921: II). У том духу, Прилози су поздравили оснивање сваког новог листа и, кад је реч о фолклористици, пропратили прве бројеве Гласника Етнографског музеја (Чајкановић 1929: 202-206) и нову посебну серију Српског етнографског зборника (Ђорђевић 1934а: 271-272). Међутим, покретање Прилога проучавағу народне поезије 1934, П. Поповић је прокоментарисао кратко и уздржано тек 1937, заједно са другим новим часописима (1937б: 287-289), али је зато Н. Банашевић раније, 1935. и 1936, у Прилозима оштро критиковао прве четири свеске овог листа. Замерао је готово све, од прве до последње стране, од наслова који асоцира на Прилоге за књижевност, језик, историју и фолклор, до лоше формулисане библио-

\footnotetext{
${ }^{6} \mathrm{O}$ поштовању које је уживао сведочи и претпоследњи број прве серије Прилога, уприличен од стране сауредника поводом његовог 70. рођендана, у коме су своје радове приложили готово сви виђенији домаћи и страни сарадници овог листа.

${ }^{7} \mathrm{O}$ српској и југословенској концепцији историје књижевности П. Поповића в. Николић 2009: 267-295.

${ }^{8}$ Понека, ретка исклизнућа из југословенске концепције заједничке традиције, интересантно су сведочанство о неодрживости наметнуте идеје. Нпр. Т. Ђорђевић је у приказу осме књиге Хрватских народних пјесама приређивачу Николи Андрићу нарочито замерио истицање „индивидуалности хрватске душе” и „хрватске душевности” (1940г: 218), Ф. Барјактаревић је бранио став о српским мевлудима, не признајући постојање босанских (1937: 2), а П. Поповић је Југословенском историјском часопису упутио апел за више ћирилице (1937б: 288-289).
} 
графије. Критиковао је усвајање нових метода прашке школе и занемаривање старих, трагање за историјском веродостојношћу и одбацивање проучавања кретања мотива, закључивање о прошлости на основу актуелног стања усмене поезије, претерано поклањање пажње певачу, прецењивање старине усмених творевина, непоуздане закључке, лако закључивање и необавештеност (Банашевић 1935: 228-231; 1936а: 119-125). И заиста, по својим доминантним тематским и методолошким преокупацијама, као што су теренска истраживања, испитивање старине, постанка и историјске веродостојности поезије, Прилози проучавағу народне поезије били су сасвим далеко од строгих, академских, званично признатих Прилога за књижевност, језик, историју и фолклор. Старији и млађи Прилози представљали су супротности: старо и ново, канонско и популарно, конзервативно и модерно, при чему се знакови „,+” или „--” ни тада, а ни данас не би могли децидирано ставити ни на једну страну. Границе нису биле непропусне, било је фолклориста који су сарађивали у оба листа, али је приметно да су најзаступљенији аутори Прилога проучавању народне поезије (Р. Меденица, А. Шмаус, С. Матић, Д. Костић, Б. Крстић, М. Лалевић, М. Филиповић, С. Стефановић, Х. Поленаковић), мало или нимало учествовали у раду Прилога за књижевност, језик, историју u фолклор. Слично је и са носиоцима фолклористике Прилога за књижевност, језик, историју и фолклор: Ф. Барјактаревић не сарађује у Прилозима проучавању народне поезије, В. Чајкановић врло мало - објавио је само два чланка (1935: 20-24; 1936: 192-202), а Т. Ђорђевић такође два текста, али је други подељен и дат у више наставака (1934б: 187-200; 1935в: 24-29; 1935г: 206-216; 1936г: 43-50; 1936д: 202-211; 1937г: 54-66; 1937д: 211-216; 1938б: 73-79; 1938в: 193-199; 1939а: 53-60; 1939б: 190-194).

Негде на средини између два Прилога стајао је Српски књижевни гласник. Као што је почетком века у своје редове примио и „деловце” и „недићевце”, окупљене око два супротстављена гласила (Поповић 1931: 32-33; Ковић 2003: 367), тако је и две-три деценије касније отворио своје странице и академским и оним мање академским фолклористима. ${ }^{9}$ Управо се на страницама Српског кюижевног гласника тридесетих година прошлог века одвијала најжешћа полемика између Н. Банашевића и Д. Костића, представника поменутих опозитних струјања тога времена. ${ }^{10}$ А када се завршио рат пером, отпочео је онај други, прави рат, који је угасио и листове и научне сукобе.

\footnotetext{
${ }^{9}$ Д. Иванић примећује упадљиву отвореност прве серије Гласника за фолклористичка истраживања (2003: 102), а то још више важи за нову серију, која се спасава „књижевне смрти” осавремењавањем (Петров 2003: 60) и интересовањем ,за поетику и естетику новог књижевног нараштаја" (Јовић 2003: 82). Према мишљењу П. Пијановића, друга серија Српског књижевног гласника одсликала је бурно међуратно доба, у коме су се преплитале разнолике књижевне идеје и покрети и када је свака група настојала да покрене своје гласило да би изразила своје поетичке идеје (2014: 332).

${ }^{10}$ Костић 1936а: 196-209; Костић 1936б: 264-280; Костић 1936в: 356-375; Костић 1936г: 211-223; Банашевић 1936б: 532-534; Банашевић 1936в: 611-622. В. о томе Петковић 2017: 91.
} 


\section{ЛИТЕРАТУРА}

Банашевић 1935: Н. Банашевић, „Прилози проучавању народне поезије, год. I, св. 1.", ПКЈИФ, XV/1-2, 228-231.

Банашевић 1936а: Н. Банашевић, „Прилози проучавању народне поезије, књ. I, св. 2, књ. II, св. 1-2.", ПКЈИФ, XVI/1, 119-125.

Банашевић 1936б: Н. Банашевић, „О постанку и развоју косовског и Марковог циклуса", Српски књижевни гласник, XVII, књ. XLVII, бр. 7, 532-534.

Банашевић 1936в: Н. Банашевић, „О постанку и развоју косовског и Марковог циклуса II", Српски књижевни гласник, XVII, књ. XLVII, бр. 8, 611-622.

Банашевић 1938: Н. Банашевић, „Један дантеовски мотив у нашој народној поезији”, ПКЈИФ, XVIII/1-2, 519-525.

Барјактаревић 1930: Ф. Барјактаревић, „Једна нова версија српскога мевлуда", 8 ПКЈИФ, Х/1, 3-87.

Барјактаревић 1934а: Ф. Барјактаревић, „Још један доказ за источно порекло наших легенада о потопу”, ПКЈИФ, XIV/1-2, 193-194.

Барјактаревић 1934б: Ф. Барјактаревић, „Насредин-хоџин проблем”, ПКЈИФ, XIV/1-2, 81-52.

Барјактаревић 1937: Ф. Барјактаревић, „О нашим Мевлудима и о Мевлуду уопште", ПКЈИФ, XVII/1, 1-37.

Будимир 1925: М. Будимир, „Будимир, Вергилијева златна грана и наш фолклор", ПКЈИФ, V/1-2, 160-179.

Вајан 1933: A. Vaillant, „Serbo-croate Davori”, ПКЈИФ, XIII/1-2, 77-80.

Геземан 1938: G. Gezeman, „Beleška o kritici teksta i stila kratke priče”, ПКЈИФ, XVIII/1-2, 577-579.

Деретић 2004: Ј. Деретић, Историја српске књижевности, Београд: Просвета.

Десница 1922: Б. Десница, „Ропство Јанковић Стојана (Историска основа Вукове песме, III, бр 25.)”, ПКЈИФ, II/2, 196-200.

Десница 1924: B. Desnica, „Jedno pismo Matije Ilijanovića Stojanu Jankoviću”, ПКЈИФ, IV/1-2, 88-91.

Десница 1926: В. Desnica, „Glagolske matice (Parohijske crkve Sv. Marije u Novigradu pod Velebitom)", ПКЈИФ, VI/2, 206-218.

Десница 1927: В. Desnica, „Nekoliko podataka o peraštanskim hajducima i o harambaši Baju Pivljaninu", ПКJИФ, VII/1-2, 179-188.

Десница 1930: Б. Десница, „Личности и прилике из прошлости Приморја”, ПКЈИФ, Х/1, 77-82.

Ђорђевић М. 1938: М. Ђорђевић, „Гуслар у савременом немачком роману”, ПКЈИФ, XVIII/1-2, 612-616.

Ђорђевић 1921а: Т. Ђорђевић, „Објашњење народних пословица”, ПКЈИФ, $\mathrm{I} / 2,224-230$.

Ђорђевић 1921б: Т. Ђорђевић, „О. Stjepan Grčić, Sinjske narodne pjesme i pričanja", ПКЈИФ, I/1, 131-132.

Ђорђевић 1922: Т. Ђорђевић, „Опростно писмо”, ПКЈИФ, II/1, 80-81. 
Ђорђевић 1927: Т. Ђорђевић, „Vejsil Ćurčić, Starinsko oružje”, ПКJИФ, VII/1-2, 336-342.

Ђорђевић 1931: Т. Ђорђевић, „Шаулић Новица, Српске народне песме I’, 243-250.

Ђорђевић 1932а: Т. Ђорђевић, “Тhe Frazer Lectures 1922-1932”, ПКЈИФ, $\mathrm{XII} / 2-3,285-287$.

Ђорђевић 1932б: Т. Ђорђевић, „О. Stjepan Grčić. Kotarske narodne pjesme”, ПКЈИФ, ХІІ/1, 158.

Ђорђевић 1932в: Т. Ђорђевић, „О. Stjepan Grčić, Kraljević Marko (po guslaru B. Domnjaku)", ПКЈИФ, XII/2-3, 285.

Ђорђевић 1933: Т. Ђорђевић, „Неколике арбанашке народне песме”, ПКЈИФ, XIII/1-2, 28-43.

Ђорђевић 1934а: Т. Ђорђевић, „Српски Етнографски Зборник, књига I, Расправе и грађа, уредио Веселин Чајкановић”, ПКЈИФ, XIV/1-2, 271-272.

Ђорђевић 1934б: Т. Ђорђевић, „Из арбанашког народног предања”, Прилози проучаваюу народне поезије, књ. I, св. 1-2, 187-200.

Ђорђевић 1935а: Т. Ђорђевић, „Шест прилога”, ПКЈИФ, XV/1-2, 191-197.

Ђорђевић 1935б: Т. Ђорђевић, „Лоше одело као заштита од урока”, ПКЈИФ, $\mathrm{XV} / 1-2,47-55$.

Ђорђевић 1935в: Т. Ђорђевић, „Белешке из наше народне поезије (I)”, Прилози проучаваюу народне поезије, књ. II, св. 1-2, 24-29.

Ђорђевић 1935г: Т. Ђорђевић, „Белешке из наше народне поезије (II)”, Прилози проучавағу народне поезије, књ. II, св. 1-2, 206-216.

Ђорђевић 1936а: Т. Ђорђевић, „Кувада”, ПКЈИФ, ХVI/2, 199-213.

Ђорђевић 1936б: Т. Ђорђевић, „Сима Тројановић”, ПКЈИФ, XVI/2, 414-415.

Ђорђевић 1936в: Т. Ђорђевић, „Новица Шаулић, Српске народне песме, књига I, свеска 4", ПКЈИФ, XV/1-2, 187.

Ђорђевић 1936г: Т. Ђорђевић, „Белешке из наше народне поезије (III)”, Прилози проучавању народне поезије, књ. III, св. 1-2, 43-50.

Ђорђевић 1936д: Т. Ђорђевић, „Белешке из наше народне поезије (IV)”, Прилози проучавању народне поезије, књ. III, св. 1-2, 202-211.

Ђорђевић 1937а: Т. Ђорђевић, „Наср-един хоџа и Арнаути”, ПКЈИФ, XVII/2, 270.

Ђорђевић 1937б: Т. Ђорђевић, „Џемс Џорџ Фрезер, Златна Грана”, ПКЈИФ, XVII/2, 350-351.

Ђорђевић 1937в: Т. Ђорђевић, допуна уз текст Х. Поленаковића, „Мијачка варијанта народне приповетке о шарану”, ПКЈИФ, XVII/2, 275.

Ђорђевић 1937г: Т. Ђорђевић, „Белешке из наше народне поезије (V)”, Прилози проучавағу народне поезије, књ. IV, св. 1-2, 54-66.

Ђорђевић 1937д: Т. Ђорђевић, „Белешке из наше народне поезије (VI)”, Прилози проучавану народне поезије, књ. IV, св. 1-2, 211-216.

Ђорђевић 1938а: Т. Ђорђевић, „Полагање самртника на земљу”, ПКЈИФ, XVIII/1-2, 468-474.

Ђорђевић 1938б: Т. Ђорђевић, „Белешке из наше народне поезије (VII)”, Прилози проучавању народне поезије, књ. V, св. 1-2, 73-79.

Ђорђевић 1938в: Т. Ђорђевић, „Белешке из наше народне поезије (VIII)”, Прилози проучавању народне поезије, књ. V, св. 1-2, 193-199. 
Ђорђевић 1939а: Т. Ђорђевић, „Белешке из наше народне поезије (IX)”, Прилози проучавағу народне поезије, књ. VI, св. 1-2, 53-60.

Ђорђевић 1939б: Т. Ђорђевић, „Белешке из наше народне поезије (X)”, Прилози проучавању народне поезије, књ. VI, св. 1-2, 190-194.

Ђорђевић 1940а: Т. Ђорђевић, „Из наших народних пословица”, ПКЈИФ, XIX/1-2, 153-156.

Ђорђевић 1940б: Т. Ђорђевић, „Наср-един хоџа у Босни”, ПКЈИФ, XIX/1-2, 153.

Ђорђевић 1940в: Т. Ђорђевић, „Порођајни демони у веровању нашега народа ('бабице')", ПКЈИФ, XIX/1-2, 8-26.

Ђорђевић 1940г: Т. Ђорђевић, „Hrvatske narodne pjesme, knjiga osma, uredio Dr . Nikola Andrić", ПКЈИФ, ХІХ/1-2, 217-218.

Живановић 1936: Ђ. Живановић, „Konsianiy Wiskowatyj, Poglosy historji polskiej w epice jugoslowianskiej”, ПКЈИФ, XVI/1, 155-159.

Иванић 2003: Д. Иванић, „Вукова школа у Српском књижевном гласнику (1901-1914)”, у: С. Тутњевић, М. Недић (ур.), Сто година „Српског књижевног гласника”, Нови Сад: Матица српска, Београд: ИКУМ, 2003, 102.

Јовић 2003: Б. Јовић, „'Стари' и 'нови', 'стари' и 'млади' - неки аспекти односа традиционално/модерно у Српском књижевном гласнику", у: С. Тутњевић, М. Недић (ур.), Сто година „Српског књижевног гласника”, Нови Сад: Матица српска, Београд: ИКУМ, 2003, 82.

Ковачевић 1932: Б. Ковачевић, „Враз и народна песма”, ПКЈИФ, ХІІ/2-3, 169-170.

Ковић 2003: М. Ковић, „Политичка улога Српског књижевног гласника (1901-1914)”, у: С. Тутњевић, М. Недић (ур.), Сто година „Српског књижевног гласника”, Нови Сад: Матица српска, Београд: ИКУМ, 2003, 363-378.

Костић 1936а: Д. Костић, „Новији прилози проучавању народне поезије”, Српски књижевни гласник, XVII, књ. XLVII, бр. 3, 196-209.

Костић 1936б: Д. Костић, „Најновији прилози проучавању народне поезије II”, Српски књижевни гласник, XVII, књ. XLVII, бр. 4, 264-280.

Костић 1936в: Д. Костић, „Најновији прилози проучавању народне поезије III”, Српски књижевни гласник, XVII, књ. XLVII, бр. 5, 356-375.

Костић 1936г: Д. Костић, „Најновији прилози проучавању српске поезије”, Српски књижевни гласник, XVII, књ. LXVIII, бр. 3, 211-223.

Кронија 1938: A. Cronia, „Preromanticismo italiano - Alberto Fortis - Poesia popolare serbo-croata", ПКЈИФ, XVIII/1-2, 546-553.

Лесковац 1936: М. Лесковац, „Четири нештампана писма Ст. М. Љубише”, ПКЈИФ, VI/1, 133-135.

Љацка 1933: В. Љацка, „Ђорђе Поливка”, ПКЈИФ, ХІІІ/1-2, 244-245.

Љацки 1936: Е. Љацки, „Неколико тумачења мога гледишта на Слово о пуку Игорову", ПКЈИФ, XVI/1, 1-8.

Љацки 1938: Е. Љацки, „Аналогије у постанку руских историских песама и бугарштица", ПКЈИФ, XVIII/1-2, 495-499. 
Мазон 1938: A. Mazon, „Claude Fauriel et les chansons de quete serbes en Sorbonne", ПКЈИФ, XVIII/1-2, 458-467.

Маретић 1930: Т. Маретић, „Још неколико речи о Ивану Сењанину”, ПКЈИФ, $\mathrm{X} / 2,245-246$.

Матицки 2003: М. Матицки, Трагом утврђивања српске књижевне традиције, у: С. Тутњевић, М. Недић (ур.), Сто година „Српског књижевног гласника": аксиолошки аспект традиције у српској књижевној периодищи, Нови Сад: Матица српска, Београд: ИКУМ, 45-51.

Милошевић Ђорђевић 2000: Н. Милошевић Ђорђевић, „Павле Поповић и изучавање народне књижевности", у: Н. Милошевић Ђорђевић (ур.), Народна књижевност, Сабрана дела Павла Поповића, књ. III, Београд: Завод за уџбенике и наставна средства, 2000, 127-133.

Миљковић 1921: Б. Миљковић, „љубомир Стојановић: Живот и рад Вука Стеф.. Караиића", ПКЈИФ, I/1, 139.

Мирковић 1923а: Л. Мирковић, „Опросно писмо”, ПКЈИФ, III/1-2, 231-236. Мирковић 1923б: Л. Мирковић, „Хришћанско-етички и хеортолошки елеменат у две народне песме", ПКЈИФ, III/1-2, 141-149.

Мирковић 1926: Л. Мирковић, „Богојављенске народне песме”, ПКЈИФ, $\mathrm{VI} / 2,202-205$.

Николић 2009: Н. Николић, „Концепције српске и југословенске књижевности Павла Поповића", Зборник Матице српске за књижевност и језик, 2009, књ. 57, св.2, 267-295.

Павловић 1959: Д. Павловић, „Павле Поповић као научник и књижевни историчар", ПКЈИФ, ХХV, 197-208.

Палавестра 1979: П. Палавестра, „Павле Поповић и историјска критика у српској књижевности", Научни састанак слависта у Вукове дане, св. 9, Београд: МСЦ, 235-251.

Петковић 2017: Д. Петковић, „Драгутин Костић као проучавалац усмене традиције”, у: Б. Сувајџић (ур.), Савремена српска фолклористика IV, Београд: Удружење фолклориста Србије, Универзитетска библиотека „Светозар Марковић”, 83-99.

Петров 2003: А. Петров, „Српски книжевни гласник и процеси осавремењавања и онесавремењавања у књижевности", у: С. Тутњевић, М. Недић (ур.), Сто година „Српског књижевног гласника”, Нови Сад: Матица српска, Београд: ИКУМ, 2003, 60.

Pešić, Milošević Đorđević 1984: R. Pešić, N. Milošević Đorđević, Narodna književnost, Beograd: IRO „Vuk Karadžić”, 1984.

Пијановић 2014: П. Пијановић, Српска култура 1900-1950, Београд: Службени гласник, 2014.

Поленаковић 1937: Х. Поленаковић, „Мијачка варијанта народне приповетке о шарану", ПКЈИФ, XVII/2, 275.

Поливка 1927: Ј. Поливка, „Две приповетке о метаморфози спола у околини Солуна", ПКЈИФ, VII/1-2, 1-22. 
Поповић В. 1934: В. Поповић, „Педесетогодишњица прве научне публикације Сер Џемса Фрезера и библиографија његових радова", ПКЈИФ, $\mathrm{XIV} / 1-2,215-216$.

Поповић В. 1938: В. Поповић, „Сер Џон Бауринг”, ПКЈИФ, XVIII/1-2, 554-564.

Поповић Д. 1928: Д. Поповић, „О мартолосима у турској војсци”, ПКЈИФ, VIII/1-2, 213-229.

Поповић 1921: П. Поповић, „Уводна реч”, ПКЈИФ, I/1, стр. I-VI.

Поповић 1922a: П. Поповић, „Owen Meredith (first Earl of Lytton), Serbski pesme, or National songs of Serbia", ПКЈИФ, II/1, 106-109.

Поповић 1922б: П. Поповић, „Народне умотворине. Српске народне приче. Из збирке народних приповједака Новице Шаулића. Књ. І. св. І.”, ПКЈИФ, II/1, 100-101.

Поповић 1924: П. Поповић, „љуб. Стојановић: Живот и рад Вука Стеф. Карачића", ПКЈИФ, IV/1-2, 301-307.

Поповић 1926: П. Поповић, „Вук Стеф. Караџић, Одабране стране. Пробрао Љуб. Стојановић”, ПКЈИФ, VI/1, 115.

Поповић 1931: П. Поповић, „Сећања на Љубомира Стојановића”, ПКЈИФ, XI, 30-44.

Поповић 1932: П. Поповић, „Новица Шаулић. Српске народне приче. Књ. I, св. 3", ПКЈИФ, ХІІ/2-3, 283-285.

Поповић 1934: П. Поповић, „Krešimir Georgijević. Novija hrvatska komedija (Od llirskog pokreta do kraja XIX veka)", ПКЈИФ, XIV/1-2, 241.

Поповић 1937a: П. Поповић, „Драг. Костић, Три песме о 'naденију Сербије год. 1813' у песмарици војвођанских ђака", ПКЈИФ, ХVII/2, 297-298.

Поповић 1937б: П. Поповић, „Југословенски историски часопис”, ПКЈИФ, XVII/2, 287-289.

Поповић 1940: П. Поповић, „Један заборављен чланак Вуков”, ПКЈИФ, XIX/1-2, 1-7.

Радојчић 1925: Н. Радојчић, „Два Вукова писма Копитару”, ПКЈИФ, V/1-2, $223-225$.

Руварац 1922: Д. Руварац, „Опросно писмо”, ПКЈИФ, II/2, 264-265.

Селесковић 1937: М. Селесковић, „Вук Караџић и Georg Heinrich Pertz”, ПКЈИФ, XVII/1, 81-89.

Стевановић 1938: П. Стевановић, „Извор једне народне приповетке”, ПКЈИФ, XVIII/1-2, 595-601.

Стојановић 1921: Љ. Стојановић, „Млади Вук”, ПКЈИФ, I/1, 1-11.

Стојановић 1922: Љ. Стојановић, „Реља од Пазара”, ПКЈИФ, II/1, 88.

Томановић 1934: В. Томановић, „Једно Вуково писмо”, ПКЈИФ, XIV/1-2, 186-188.

Томић 1928: Ј. Томић, „О Сењанину Иву (једно писмо његово и коментар)”, ПКЈИФ, VIII/1-2, 1-11.

Ћоровић 1921: В. Ћоровић, „Мотиви у предању о убиству цара Уроша”, ПКЈИФ, I/2, 190-202.

Ћоровић 1929: В. Ћоровић, „Glasnik dubrovačkog učenog društva Sv. Vlaho, knj. I", ПКЈИФ, IX/1-2, 208-210. 
Ћоровић 1931: В. Ћоровић, „Љубомир Стојановић”, ПКЈИФ, ХІ, 1-29.

Ћоровић 1932: В. Ћоровић, „Јован Томић”, ПКЈИФ, ХІІ/2-3, 71-100.

Ћоровић 1936: В. Ћоровић, „Драгутин Костић, Кад је рођен Марkо Краљевић?", ПКЈИФ, XVI/1, 177.

Филиповић 1937: М. Филиповић, „Olive Lodge, Džamutra, or the Bridegroom, Some Marriage Customs in the villages Around Tetovo in Serbien Macedonia or Southern Serbia", ПКЈИФ, XVII/1, 180-182.

Чајкановић 1921a: В. Чајкановић, „De argumento et fontibus proverbii Serbici 4 Vuk", ПКЈИФ, I/1, 65-70.

Чајкановић 1921б: В. Чајкановић, „Из наших народних пословица”, ПКЈИФ, $\mathrm{I} / 2,203-211$.

Чајкановић 1922а: В. Чајкановић, „Kasumović Dr. Ivan, Hrvatske i srpske narodne poslovice spram grčkih $i$ rimskih poslovica $i$ krilatica", ПКЈИФ, II $/ 2,284-288$.

Чајкановић 1922б: В. Чајкановић, „Kasumović Dr. Ivan, Još jedna rukovet naših paralela k rimskim i grčkim poslovicama i poslovičnim izričajima", ПКЈИФ, II/2, 288-289

Чајкановић 1923: В. Чајкановић, „Божићна слама”, ПКЈИФ, III/1-2, 123-132.

Чајкановић 1925a: В. Чајкановић, „Каскалов дућан”, ПКЈИФ, V/1-2, 241.

Чајкановић 1925б:В. Чајкановић, Schneeweis Dr. Edmund, Die Weinachtsbrauche der Serbo-Kroaten", ПКЈИФ, V/1-2, 318-322.

Чајкановић 1926а: В. Чајкановић, „Оbjectus pectorum”, ПКЈИФ, VI/1, 49-53.

Чајкановић 1926б: В. Чајкановић, „Новица Шаулић, Српске народне приче, из збирке народних приповједака, књига прва, свеска II", ПКЈИФ, VI/2, 329-331.

Чајкановић 1929: В. Чајкановић, Гласник Етнографског Музеја у Београду. Књига прва", ПКЈИФ, IX/1-2, 202-206.

Чајкановић 1935: В. Чајкановић, „Светац на десном рамену”, Прилози проучавању народне поезије, књ. II, св. 1-2, 20-24.

Чајкановић 1936: В. Чајкановић, „По греху родитељ”, Прилози проучавању народне поезије, књ. III, св. 1-2, 192-202.

Чајкановић 1937a: В. Чајкановић, „De nucibus in romanorum nuptiis usurpatis”, ПКЈИФ, XVII/1, 94-101.

Чајкановић 1937б: В. Чајкановић, „Егхутрібтоб”, ПКЈИФ, XVII/2, 249-252.

Чајкановић 1937в: В. Чајкановић, „Edmund Schneeweis, Slavische Sagen aus der Čehoslovakischen Republik, ausgewahlt und herausgegeben”, ПКЈИФ, $\mathrm{XVII} / 2$, 351-352.

Чајкановић 1938: В. Чајкановић, „Роetae Serborum epici quid et de interitu et de renovatione mundi sibi finxerint”, ПКЈИФ, XVIII/1-2, 475-494.

Чајкановић 1940: В. Чајкановић, „Прича о човеку који је преварио смрт”, ПКЈИФ, XIX/1-2, 142-149.

Чубриловић 1938: В. Чубриловић, „Сењанин Иво”, ПКЈИФ, XVIII/1-2, 526-545.

Шмаус 1938: А. Шмаус, „Курипешићев извештај о Косовском боју”, ПКЈИФ, XVIII/1-2, 509-518. 


\section{Danijela Petković \\ FOLKLORE ON THE PAGES OF THE PRILOZI ZA KNJIŽEVNOST, JEZIK, ISTORIJU I FOLKLOR BETWEEN THE TWO WORLD WARS}

(Summary)

Folklore articles have an important place in the Prilozi za književnost, jezik, istoriju i folklor in the period between the two world wars. There are about 350 folklore articles, in the form of debates, small notes and reviews of new editions. Most of them research motifs, variants, their origins and transmission routes, and after that the most numerous articles research the historical core of oral poetry. All texts are linked by similar thematic and similar methodological approach, in which the comparative method is dominant. This conception is closely related to the ideas and scientific-critical position of Pavle Popović, the founder and the editor of the Prilozi. Veselin Čajkanović and Tihomir Đorđević also play an important role in the Prilozi. When we talk about the dominant topic and methods in folklore in the period between the two world wars, the Prilozi za književnost, jezik, istoriju i folklor is in the opposite position in relation to the Prilozi proučavanju narodne poezije, and the Srpski književni glasnik is in the mid-point between these two journals. 